\title{
Patronal Care and Maternal Feeling: New Correspondence between Ann Yearsley and Hannah More
}

Keywords: patronage, motherhood, correspondence, Yearsley, Bloomfield, gratitude

Ann Cromartie, later Yearsley, was born in Clifton in 1753, and came to prominence in the 1780s as 'The Bristol Milkwoman', a poetical phenomenon 'discovered' by Hannah More in the autumn of 1784. Little is known about Yearsley's early years, but what is known has been carefully recorded by Mary Waldron in her 1996 biography, Lactilla, Milkwoman of Clifton. ${ }^{1}$ Taught to read by her mother and to write by her brother, Ann Cromartie was married at 21 to John Yearsley, a yeoman. Although their marriage seems to have begun well enough, with five children born between 1775 and 1782, by the winter of 1783-4 the Yearsley family were in extreme difficulties (Waldron, 18). Starving in a barn, Yearsley, her husband, her mother, and the five children were rescued at the last by a local man, Mr. Vaughan, though too late to save the life of Mrs. Cromartie, who died shortly afterwards. The family's fortunes recovered, and by autumn 1784 Yearsley was selling milk and collecting hogswash door to door. Her extraordinary story came to the attention of Hannah More, whose cook was one of those on whom Yearsley called for hogswash.
Hannah More, playwright, poet, and educational reformer, was also a native of the Bristol area. Jilted by her fiance, More was made financially independent by a $£ 200$ annuity paid in lieu of the wedding. Although More made use of this independence by establishing and running Sunday schools, as well as supporting other charitable and literary projects, her social position was inevitably dubious; More's connections with a conservative evangelical circle assured a respectability which might otherwise have been in doubt. When More decided to patronise Ann Yearsley, therefore, it was not from a position of clear class or social superiority, a fact which would come to be extremely significant in the eventual breakdown of their relationship.

Nevertheless, upon reading a sample of Yearsley's poetry, More set about raising a subscription for a volume of the milkwoman's verse. Poems on Several Occasions was published in June 1785, bearing the names of over 1000 subscribers, many of them high-ranking nobility, and many of them friends and acquaintances of More's. $£ 500$ was generated, and placed in trust by More and Elizabeth Montagu, a fellow Bluestocking, and a woman who had had considerable experience of patronising a labouring-class poet through her long association with James Woodhouse. In 


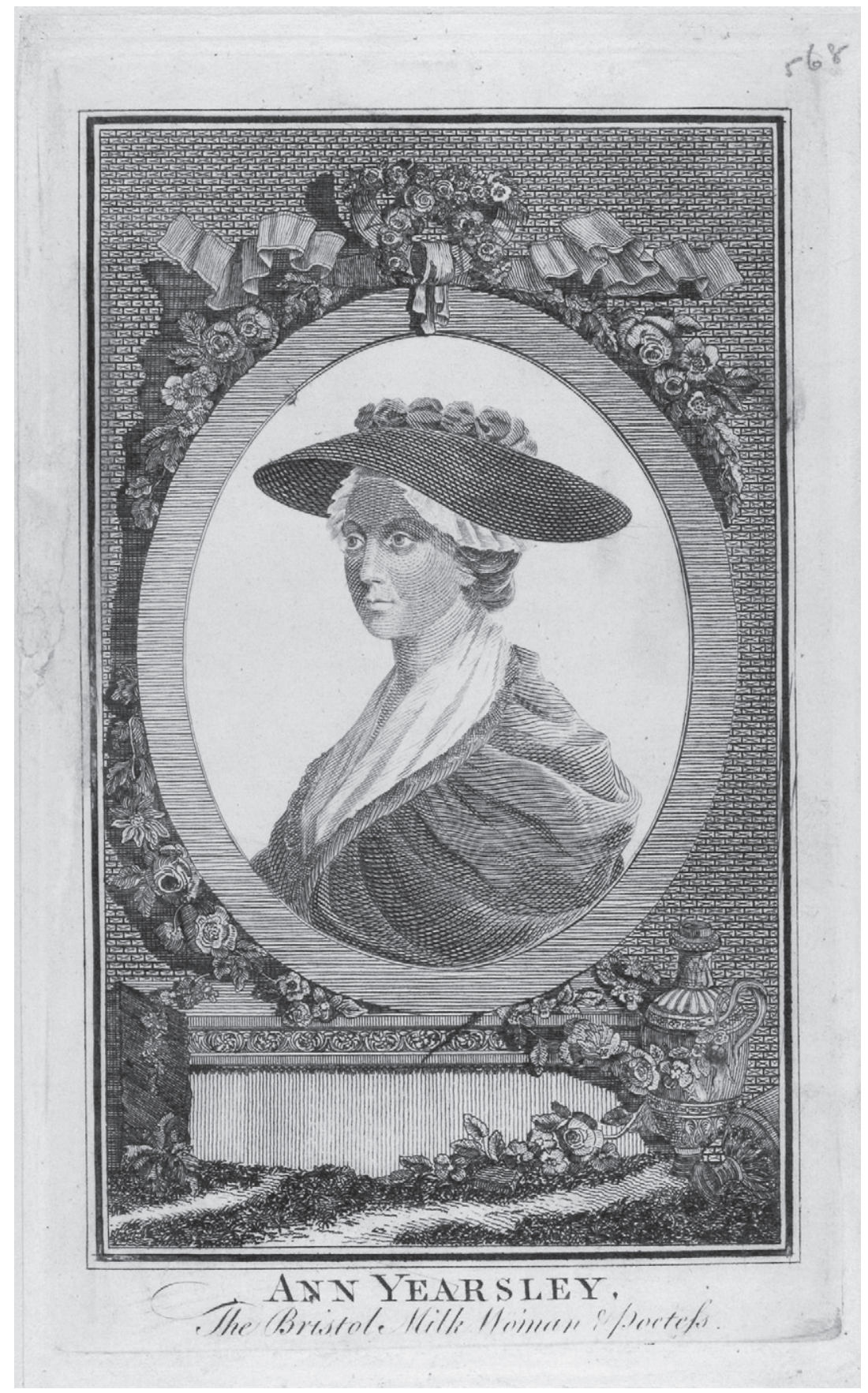

Figure 1. William Lowry, 1787, engraving, after an unknown artist. Alice Bemis Taylor Autograph Collection, MS 0145, letter from Ann Yearsley, Colorado College Special Collections. 
July 1785, only a month after publication, tensions began to surface regarding More's handling of Yearsley's earnings, and the relationship, which had seemed so promising, fell apart within a few months. Acrimonious exchanges appeared in the local newspapers, doing little for the reputations of either woman. The situation was exacerbated for a time by the publication of 'Mrs Yearsley's Narrative' in the fourth edition of Poems on Several Occasions in 1786, where Yearsley defended herself against charges of ingratitude. However, despite the strains of the previous two years, Yearsley was able to bring out a second volume of poetry, Poems on Various Subjects, in 1787, and would go on to publish a novel (1795) and a play (1791) as well as a range of poetry. More, too, continued her career, though she was undoubtedly marked by her experiences as Yearsley's patron.

Perhaps understandably responses to Yearsley, both in the eighteenth century and more recently, have often been mediated by perceptions of her public quarrel with More. However, the exact circumstances surrounding the falling-out have remained something of a mystery. The fullest source of information is Yearsley's own 'Narrative', which must inevitably be treated with some caution, and recently More's correspondence has provided some insights into her actions. However, there has been no equivalent correspondence from Yearsley which might shed light on her reasoning. This makes the discovery of a previously unattributed letter from Ann Yearsley to Hannah More extremely important. Currently the only known correspondence between the two women, the letter, which is published here for the first time, sheds new light on their relationship. There are also implications for our understanding more widely of patronage at the end of the eighteenth century, as older modes of patronage, themselves never free from tensions over social inequality and power imbalance, were under increased pressure from the commercial ethics produced by the possibility of success on the vastly expanded book market. I will pursue some of these implications in this essay, using this new letter to sketch out an examination of poet/patron relationships as they affected other contemporary labouring-class writers. By making comparisons with Robert Bloomfield and Mary Leapor, I hope to draw some conclusions about how the language of patronage was affected by gender, how the cultural codes of femininity and gentlewomanliness shaped the relationship between More and Yearsley, and how those codes affected the language they used to negotiate that relationship.

Yearsley's previously unpublished letter is transcribed below, and is dated 13 September 1785. It is currently held in the Alice Bemis Taylor Collection at Tutt College Library in Colorado. Unfortunately, little is known about how the letter came to be in the possession of Alice Bemis Taylor, but it was bequeathed to Tutt College in the middle of the twentieth century. ${ }^{2}$ There it remained in obscurity until a project to digitise the collection allowed a Google search to locate it.

\section{Ann Yearsley to Hannah More}

Date: 13 September 1785

Address: None

Stamped: None

Postmark: None

Endorsements: [in another hand] $\operatorname{Sep}^{\text {tr }}$ the 13

1785

Seal: Unknown

Location: Alice Bemis Taylor Collection, Special Collections, Tutt Library, Colorado Springs, Colorado.

Length: 2 fols [written on $1 \mathrm{r}$ and $\mathrm{v}$ and $2 \mathrm{r}$; address leaf missing]. Includes portrait of 'The Bristol Milk Woman Poetess'.

Published: Never

Watermark: Unknown

[In another hand] Sep ${ }^{\text {tr }}$ the 131785 
Madam,

I shall begin by avowing what my feelings will never allow me to be insensible of; your goodness in protecting my publication; had your subsequent Conduct proved that protection had arisen from the humanity my situation and the distresses of my family naturaly would awaken in the breast of a Woman sensible of the feelings of a mother and concious of the charms of having dependants; my Gratitude would have known no bounds, to have ones children dependant on us is a natural desire; it is a laudable one; to usurp that power over individuals either by imposing on their Generosity or Ignorance, is most degrading;

I wish'd not for money but to enable me to bring up my children in Comfort and improvement and had you been actuated by a disinterested desire to [second?] my wishes, my sense of your benevolence Could never have been erased, but your late treatment has set a narrow bounds to my Gratitude, which Cannot be avowd for favours these Circumstances Convince me arrose [sic] more from your vanity than Generosity you tax me with ingratitude, you reproch [sic] me with obligation; for why? you found me poor yet proud, if it can be calld pride to feel too much humbled by certain obligations and above submitting to servility

You helpd to place me in the public eye; my success you think beyond my abilities; and purely arising from your protection; I wish not to lessen your favours; but granting this to your vanity; surely mine does not Soar in thinking the Singularity of my situation would have secured me some success; this will soon be tried.

And let me ask you what I have gaind by your professt friendship? I find myself deprived of the money which my poems and the torturing tale of my distress have raised; my feelings and gratitude is traduced but the public may yet discover my depressd Situation.

I wish not to squander the money my every hope of future pleasure this side eternity; Centers in my Children; but I wish not to divest myself either of the pleasure or Right I have by nature; and I repeat it, as the money was Collected in my name and for the purpose of relieving My Childrens wants; the right was mine to Educate and set them in life as their dispositions may in future determine; the public generously intended the money for this benevolent purpose and I cannot think it ingratitude to disown as obligation a proceeding which must render [my surviving?] Children [word unclear] your poor dependants forever; I have trusted more to your probity than the event justifies; you have led me to sign a settlement which defrauds me and my family of our right (and make it if ever receiv'd your peculiar Gift, ([sic] you are too sensible there is no fund specified where it is placed nor do I know how it is disposed of, there is no time assign'd when my Children shall call it out:) your bankruptcy or Death may lose it forever, and let me ask you Miss More ${ }^{3}$ what security you have ever Given my Children whereby they may prove their future Claim:? ? I am sorry remonstrance should be needful, or your motives left bare to doubt or Suspicion.

My mind is haughty, but too justly so not to glory in being ever grateful for obligation it Could stoop to recieve if I have misjudgd your Conduct; 'tis yours to Confute my opinions; it depends on this, my raising a monument in my second publication either to your Just or unjust proceeding; the choice be yours

I am yr humble servant Ann Yearsley ${ }^{5}$ 


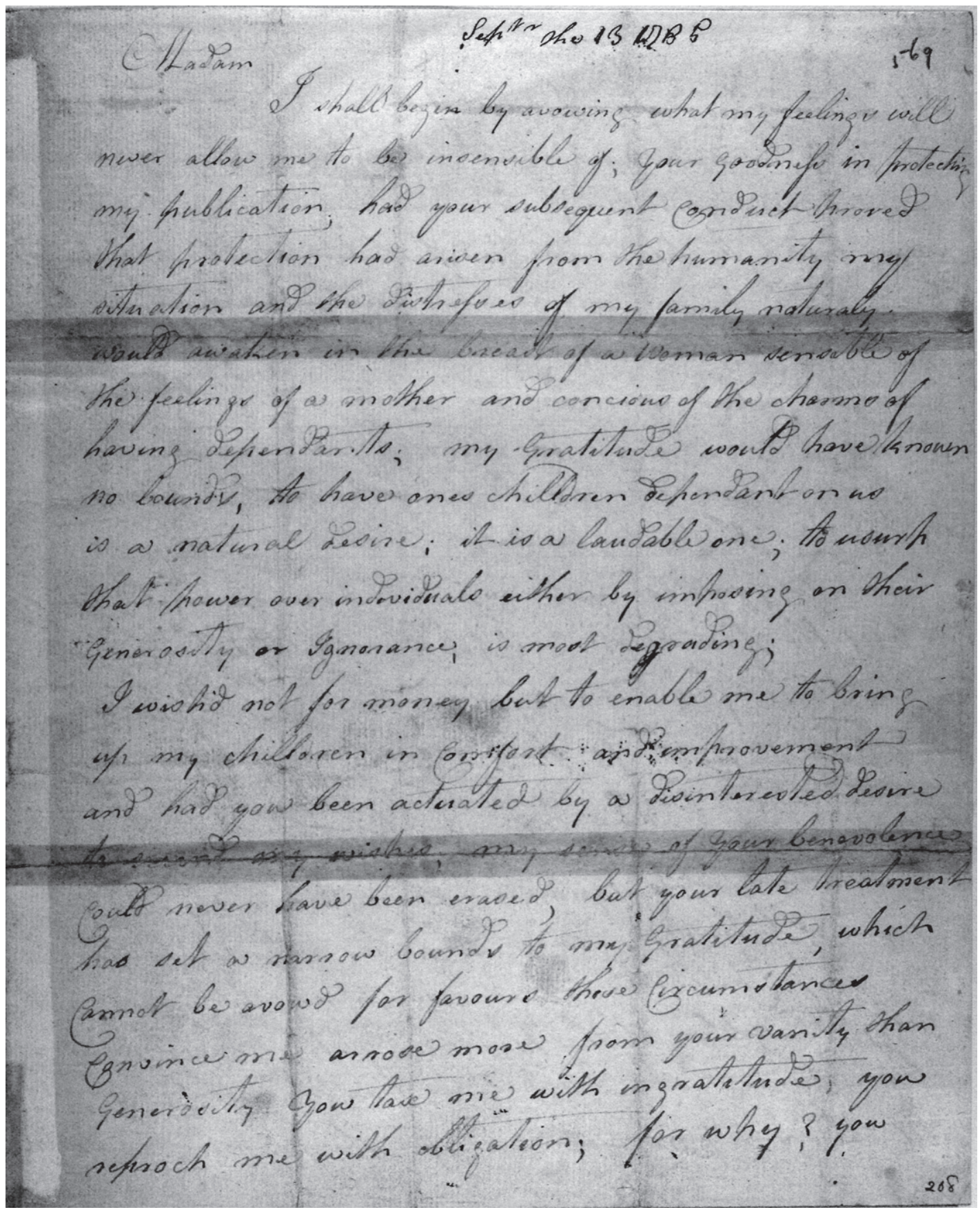

Figure 2. 1 recto of letter from Ann Yearsley to Hannah More, 13 September 1785. Alice Bemis Taylor Autograph Collection, MS 0145, letter from Ann Yearsley, Colorado College Special Collections. 
The letter was written three months after the publication of Yearsley's Poems on Several Occasions, and details Yearsley's grievances at More's conduct as a patron, as a friend, and as a woman. At the letter's heart is the issue of the Deed of Trust, a document that Yearsley signed at More's request, and which authorised Hannah More and Elizabeth Montagu, as trustees, to control the earnings from Yearsley's first publication. The money was to be put in the government stocks and the interest paid to Yearsley half-yearly. Until the discovery of this letter the only details of the disagreement over the Deed of Trust to survive are in Yearsley's own 'Narrative', attached to the fourth edition of Poems on Several Occasions (1785), and republished with her second volume of poetry, Poems on Various Subjects (1787). In the 'Narrative', Yearsley recounted her attempts to persuade More to accede to her request for a copy of the Deed of Trust. She recalls how 'It was sent to Bristol the day my books came here, with an order for it to be signed by my husband and me immediately, and returned to London the next morning. - I had no time to peruse it, nor take a copy; and from the rapidity with which this circumstance was conducted, I feared to ask it' ${ }^{6}$ Things appear to have moved fairly quickly from this point. Upon More's return to Bristol, she and Yearsley met, and met several further times, before the final dénouement after supper at the home of the More sisters. In the 'Narrative', Yearsley asked for a copy of the Deed of Trust 'for the future security of my children', whereupon More accused her of being mad, and inebriated: " "have you drank a glass too much? Who are your advisers? I am certain you have drank, or you would not talk to me in this manner." ' (Narrative, xvii).Yearsley's response was a model of wronged and virtuous motherhood:

I replied, "Madam, you are very wrong to think I have drank. I am only anxious on my children's account. Circumstances may change, ten or twenty years hence, when perhaps I am no more; and I only wish for a copy of the deed, as a little memorandum for my children; nor do I think the requisition unreasonable." (Narrative, xvii-xviii)

The eloquence, coherence, and calmness of this reply argue against it being an entirely accurate reflection of the heated exchange in Hannah More's house. What we can see, though, are the similarities between the 'Narrative' and Yearsley's letter to More. In both, the injustice of More's behaviour is coded in the language of maternal distress, and Yearsley uses this language to condemn More as a woman, whose failure to show proper feminine feelings towards Yearsley's children is offered as evidence of her failings as a patron and a friend.

This is a shrewdly directed blow. As a prominent Bluestocking and an unmarried professional woman, Hannah More was vulnerable to attacks which picked up on her unorthodox status. This vulnerability was most brutally exposed in 1799 with John Wolcot's vicious satire on More's Strictures on the Modern System of Female Education (1799) and her connection with Bishop Porteus. In his Nil Admirari; or, A Smile at a Bishop, Wolcot constructs a distinctly sexually-charged atmosphere: 'And lo, this varnish with thy daubing brush / Smear'd o'er Miss Hannah must by time be roasted, / The nymph in all her nakedness will blush, / And courtly Porteus, for a flatterer posted'. As Noah Heringman has argued, Wolcot's 'own heterosexually charged masculinity rides triumphant [... and] eroticizes the relation between More and Porteus ${ }^{\prime}{ }^{8}$ Unmarried, More's sexuality is an easy target for the satirist, especially as in Strictures More takes great pains to stress the importance of marriage and motherhood as appropriate roles for women.

Yearsley plays on More's vulnerability when she states at the beginning of her letter, 


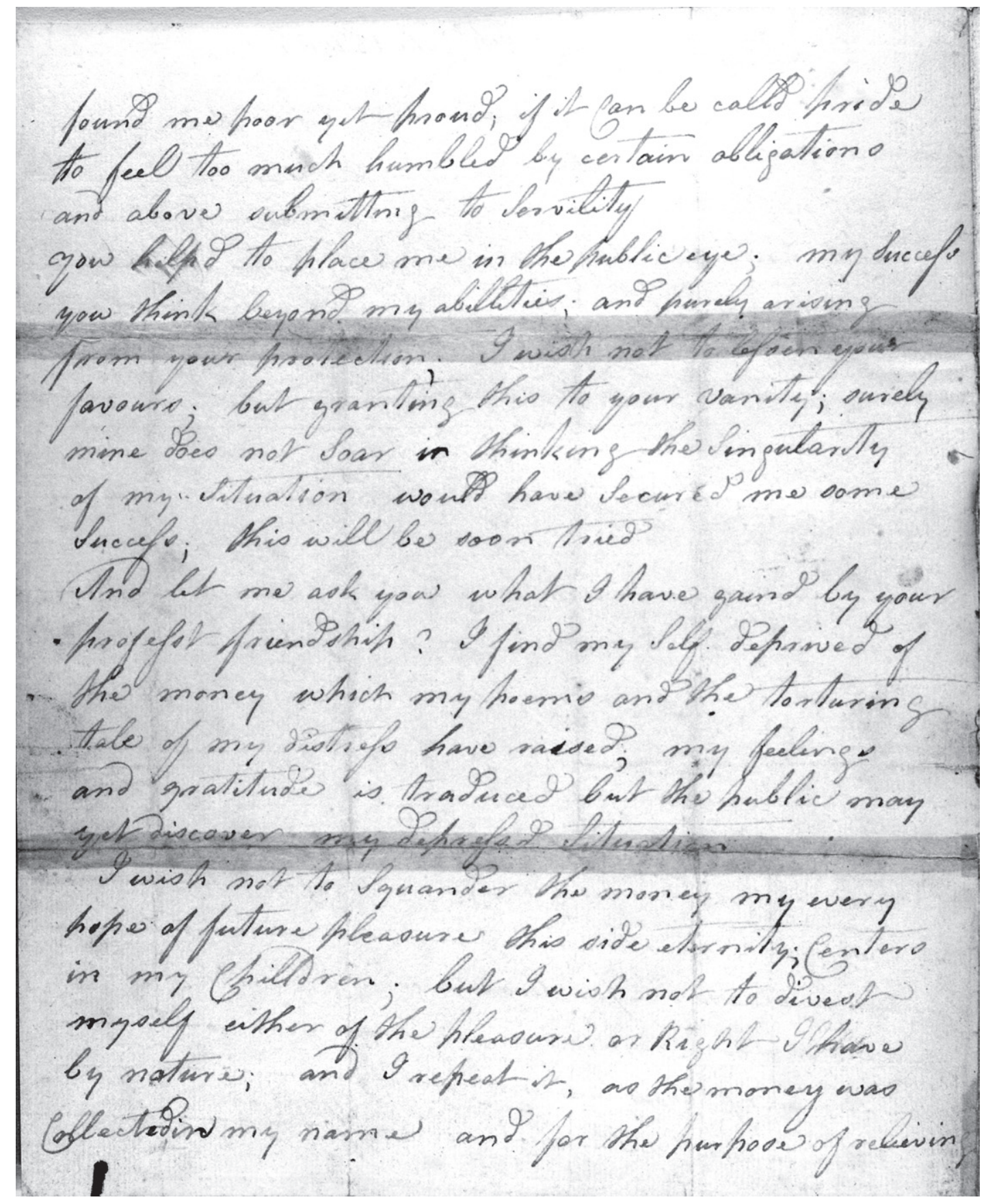

Figure 3. 1 verso of letter from Ann Yearsley to Hannah More, 13 September 1785. Alice Bemis Taylor Autograph Collection, MS 0145, letter from Ann Yearsley, Colorado College Special Collections. 


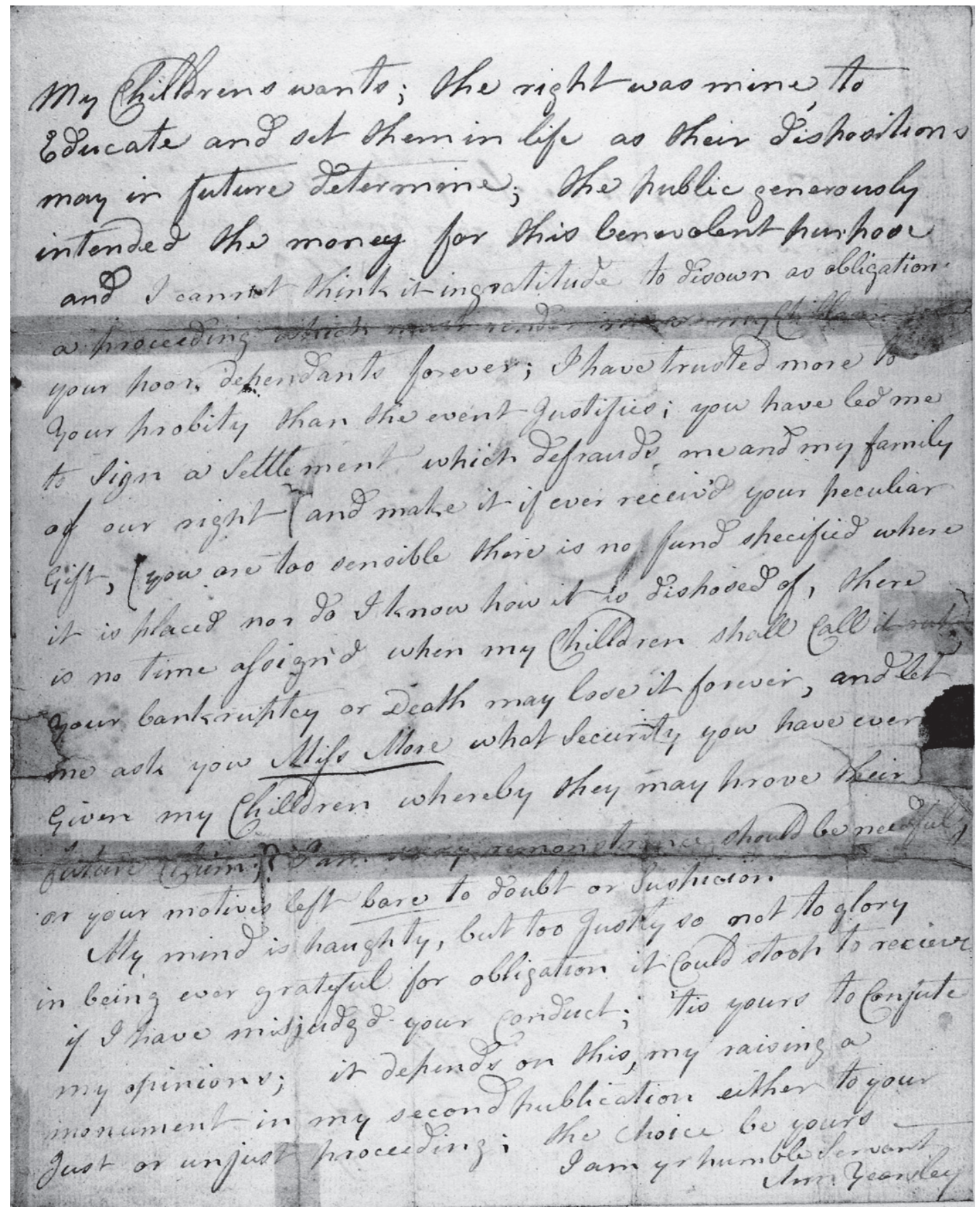

Figure 4. 2 recto of letter from Ann Yearsley to Hannah More, 13 September 1785. Alice Bemis Taylor Autograph Collection, MS 0145, letter from Ann Yearsley, Colorado College Special Collections. 
'had your subsequent Conduct proved that protection had arisen from the humanity my situation and the distresses of my family naturaly would awaken in the breast of a Woman sensible of the feelings of a mother [...] my Gratitude would have known no bounds'. ${ }^{\prime}$ Yearsley's choice of terms here is telling. The 'naturalness' of 'humanity' is implicitly contrasted with the unnaturalness of More's behaviour: she is rendered both unwomanly and inhuman. Simultaneously, Yearsley's failure to feel 'Gratitude' is entirely natural-she, as a mother, has no obligation to show 'Gratitude' to a woman with such deviant feelings. However, this exchange is merely a preliminary to the letter's main allegation. Yearsley writes, 'to have ones children dependant on us is a natural desire; it is a laudable one; to usurp that power over individuals either by imposing on their Generosity or Ignorance, is most degrading' (Yearsley to More, 13 September 1785). Hannah More is a usurper, taking from Yearsley her children's dependence upon her, and perhaps replacing and 'degrading' her as the mother in the Yearsley family.

The importance of this cannot be overestimated. Hannah More had made sure Yearsley's maternity was highly prominent in her 'Prefatory Letter' to Poems on Several Occasions, and heavily emphasised her status as a wife and a mother:

She is about eight-and-twenty, was married very young, to a man who is said to be honest and sober, but of a turn of mind very different from her own. Repeated losses, and a numerous family, for they had six children in seven years, reduced them very low, and the rigours of the last severe winter sunk them to the extremity of distress [...] Her aged mother, her six little infants, and herself (expecting every hour to lie in), were actually on the point of perishing, and had given up every hope of human assistance, when the Gentleman, so gratefully mentioned in her Poem to STELLA, providentially heard of their distress, which I am afraid she had too carefully concealed, and hastened to their relief. The poor woman and her children were preserved. ${ }^{10}$

Yearsley's fertility is beyond doubt; she has had a baby almost every year, and might at any moment produce another. As a woman, then, Yearsley is fulfilling her obligations to society by propagating the species, yet she is being cast as a 'poor woman' in more than one way. She may be a mother in the biological sense of the word, but More's account makes it clear that she is unable to provide for her children. She is literally a 'poor woman', without money, but she has also failed to take the steps necessary to preserve her children: she has 'too carefully concealed' the family's distress, and the arrival of aid is the result of mere chance. Yearsley's reference in her letter to her 'natural desire' to have her children dependent upon her is therefore loaded with significance. However, if More is the 'usurper' of maternal influence in the family, Yearsley's own position becomes rather difficult. Yearsley would sum up this difficulty in her 'Narrative': 'I felt as a mother deemed unworthy the tuition or care of her family; and imagined my conduct and principles must of necessity be falsely represented to a generous public, in order to justify the present measure' (Narrative, xvi). The 'present measure' is the Deed of Trust, and if Yearsley is 'unworthy the tuition or care of her family', she is no mother. No longer the mother of the family, Yearsley is effectively infantilised: she has become a dependant of More's.

Yearsley's struggle with More over the way she was introduced to the public was not unique; several labouring-class poets expressed, in public or in private, anxiety and anger at the way in which they were represented by their patrons. Indeed, Robert Bloomfield's letter in October 1801 to Capel Lofft, in which he talks 
of 'a praise too direct, if not premature, [which] is made to meet the publick eye' in the latest edition of The Farmer's Boy, echoes the difficulties sixteen years previously between Yearsley and More. ${ }^{11}$ Bloomfield's distress over his patron's conduct is clear: 'These notes, Sir, will be disapproved, I know they will' (Bloomfield to Lofft, 22 October 1801), yet Lofft's angry response is based on his sense that his patronal privileges have been brought into question, or even curtailed, by the poet's unreasonable exercise of his authorial power:

I do not mean to write either note or essay to any future edition of any poems you may publish in my Life-time. I assure I can very ill spare the time short as the notes are. [...] Mind, I could not well take any part that was more modest, or offer an opinion in fewer words. You, and you say your friends in general, are, or will be, dissatisfied with them and dislike my occupying even so small a space in your works and so unobtrusive a station as the bottom of the page. I believe you will find me assuredly resolved not to occupy any space at all in them in future; only if I must not say what I think of you it would have been as well if you, in your preface, had not said what you think of me. In future if I am to be silent as to your praise in your publications I would request you to be so as to mine reciprocally. ${ }^{12}$

Lofft's description of his 'station' 'at the bottom of the page' here is particularly interesting. Lofft, like Hannah More, has found that with his client's success came increased confidence, and the end of the exclusive reliance on one patron. The phrasing of the conclusion of Lofft's letter carefully plays on this apparent disruption of patronal power: 'I am ready at all times to do what essential services I can, but such punctilios I do not like nor expect from a man of genius' (Lofft to Bloomfield, 24 October 1801). Lofft is Bloomfield's 'servant', rendering the novice poet the 'essential services' of benevolent patronage. By excluding Lofft, who has petitioned so humbly to be allowed to 'serve', Bloomfield is, by implication, guilty of ingratitude and pride.

There are interesting comparisons to be made here with Samuel Johnson's famous letter to Lord Chesterfield. In this case, the would-be client is the one capable of manipulating the language of patronage. Of course, Johnson, by the time he came to write his letter, was an established writer of significant independent reputation, in a much more powerful position than either Yearsley or Bloomfield; Johnson was secure enough to allow his exquisitely polite satirisation of patronage, his almost forensic disection of Chesterfield's conduct, to become public. In many ways it is this transformation, from impoverished writer to confident and independent professional, that both More and Lofft feared in their protégés, and with good reason:

Is not a patron, my Lord, one who looks with unconcern on a man struggling for life in the water, and, when he has reached ground, encumbers him with help? The notice which you have been pleased to take of my labours, had it been early, had been kind; but it has been delayed till I am indifferent, and cannot enjoy it; till I am solitary, and cannot impart it; till I am known, and do not want it. ${ }^{13}$

The key phrase is the last: 'till I am known, and do not want it.' As both Yearsley and Bloomfield begin to appreciate the power they had suddenly come to possess, they no longer stood in such need of their patrons. From the correspondence of both More and Lofft, this did not escape the patrons' notice. However, even though Johnson had no need to fear the consequences of allowing this letter to be made public, the power difference between himself and Lord Chesterfield, of a magnitude similar at least to that which lay between Bloomfield and 
Lofft, meant that the attack appears to have achieved very little. Although Boswell writes posthumously 'That Lord Chesterfield must have been mortified by the lofty contempt [...] it is impossible to doubt, he reports a conversation between Dr Adams and Robert Dodsley where Dodsley exclaims, in response to Adams' suggestion that 'Lord Chesterfield would have concealed' the letter, 'Poh! [...] do you think a letter from Johnson could hurt Lord Chesterfield?' (Boswell, 143) Whether it did or not (and Boswell argues that it certainly did 'hurt' Lord Chesterfield) is a matter for speculation. What is interesting, though, is Dodsley's reaction - it is seen as a matter of course that Johnson could not hurt so great a man as Chesterfield. In effect, even though Johnson had long since ceased to be in the position of client to Chesterfield, his ability to respond was still framed, even limited, by the power dynamics inherent to patronage.

Bloomfield appears to have been only too conscious of the limitations of his ability as a client to protest against Lofft's public and private treatment, the consequences of those same power dynamics. His response to Lofft's accusations of neglect demonstrate a particular awareness of how Lofft was manipulating his role as patron:

If I felt that I deserved these severe censures, I should be miserable; as I know that I do not, my mind shall be easy come what will. To write my thoughts I see is impossible without lessening that high opinion which has been professed for me. I have been extravagantly applauded; few men have had a severer trial. My Modesty have been extoll'd; my insolence shall not take place of it in any ones mind, unless what I now write be so termd. I feel my situation to be novel; the world looks at me in that light. ${ }^{14}$

The charge here is 'insolence', but the similarities with Yearsley's attempts to repel accusations of ingratitude are unmistakable. Bloomfield's description of having been 'extravagently applauded' mirrors Yearsley's account in her 'Narrative'. Reminding her readers that More had previously called her 'pious, umambitious, simple and unaffected in her manners', Yearsley continues:

These, with many more perfections, are the ornament with which this very consistent lady has thought fit adorm the Milkwoman of Clifton! But, alas! how fallacious is eloquence! how inconsistent capricious affection, when steady principle is not the basis! - From elaborate commendation, the elevated Stella descends to low scurillity, charging me with "drunkenness," "gambling," "extravagance," and terming me "wretched," "base," "ungrateful," "spendthrift". (Narrative, xix)

For both Bloomfield and Yearsley, the power of representation lies with the patron: attempts by the poets themselves to alter, or to ask for an alteration in that representation, are cast by both More and Lofft as deviations from appropriate client behaviour. Their attempts, in either public or private, to attack or at least challenge the representations of their patrons, appear to be limited by the same assumptions at work in Dodsley's reaction to Johnson's letter.

Matters stood rather differently between Mary Leapor and her patron Bridget Freemantle. Here, the power of representation lay entirely with her patron, and it was absolute. With the poet's death before publication of her verse, there could be no awkward complaints about patronal interference, or misrepresentation. Although Freemantle indicates that Leapor intended to correct her poetry had she lived, pleasure is expressed that the poems will 'now appear in their native Simplicity' ${ }^{15}$ It is allowed that the corrections would have 'greatly improved' the poems, but uncorrected they are able to 'serve 
as a convincing Proof of the common Aphorism, Poeta nascitur, non fit' ('To the Reader', no pagination). Interestingly, the preface states that 'if the Poems will not recommend themselves to the Reader, little Advantage is to be expected from any thing that can be said of them here', although it is felt necessary to remind the reader that Leapor was 'contented in the Station of Life in which Providence had placed her' ('To the Reader', no pagination). This address 'To the Reader' is not free from the language of natural genius, humbleness, or gratitude which characterises the later prefaces to Yearsley's and Bloomfield's work, but its willingness to allow the poetry to speak for itself does stand in contrast to More's and Lofft's approach, which sought to make their clients' reputation dependent upon their patrons' good word.

However, dependent is what Bloomfield, and Yearsley, were supposed to be. Their status as clients implies a certain element of servility, and it is the patron's right (and obligation) to supply the protégée with, as Dustin Griffin notes, 'encouragement', 'protection', 'favour', and what Griffin terms 'familiarity', 'whereby people of talent are permitted to cross a line, under controlled conditions, that normally separates the ranks of a hierarchical society ${ }^{\prime}{ }^{16}$ More makes doubly sure of her right to act as she has by casting herself as the gentlewomanly protector of Yearsley and her family. In this role More has a social duty to assist those worse off than herself, and makes clear to the subscribers that that assistance must needs be more than a gift of money. Mr. Vaughan may have saved the family from the immediate danger of starvation in a barn, but it is More who has the ability, as a well-connected, well-known writer, to assist Yearsley in the longer term, the embodiment of middling-class gentlewomanliness.

Subject to these two significant social institutions, patronage and middling-class charity, both of which dictate that she should be the grateful object of philanthropic gestures, Yearsley must deploy her only socially-approved source of power in order to assert her case for self-determination. Her letter's conclusion sees this power wielded to great effect. Building on the strategies deployed in the opening paragraph, Yearsley again couches her concerns for her children in terms of what is 'natural', and in terms of her 'rights' as a mother. Yearsley also manages to turn the telling of the 'torturing tale' of her 'distress' into a matter of motherhood: More has used Yearsley's motherhood to solicit contributions, and cannot now withhold those contributions from the mother without defrauding both her and the public. Indeed, this is the term Yearsley herself uses, accusing More of having compelled her 'to sign a settlement which defrauds me and my family of our right' (Yearsley to More, 13 September 1785). And in contrast to the image of stoic but ineffectual motherhood presented by More in her 'Prefatory Letter', Yearsley demonstrates the depth of her understanding about funds and their management:

you are too sensible there is no fund specified where it is placed nor do I know how it is disposed of, there is no time assign'd when my Children shall call it out:) your bankruptcy or Death may lose it forever, and let me ask you Miss More what security you have ever Given my Children whereby they may prove their future Claim:? (Yearsley to More, 13 September 1785)

More is in the wrong legally, socially, and collegially; she is accused of fraud, and she has bypassed, and attempted to neutralise, the authority of a mother.

More's punishment is to face trial by public opinion. Yearsley concludes her letter with the threatening statement that it depends on this, my raising a monument in my second publication either to your Just or unjust proceeding; the choice be yours' (Yearsley to 
More, 13 September 1785). Yet rather than defending herself in the public arena, a tactic she had found to be counterproductive when refuting Hannah Cowley's accusations of plagiarism in 1779, More prefered to wage a private battle against Yearsley. Three days after receiving the letter from Yearsley, Hannah More wrote to Elizabeth Montagu in anguish over the behaviour of her former protégée. In this letter More transcribed a large section of Yearsley's correspondence, framing it with her own version of events. More's letter to Montagu survives in the Huntington Library, but with the discovery of the original from Yearsley it takes on a much greater importance than it previously had. Only now, when the two letters can be compared for the first time, is it possible to see the means by which the quarrel between More and Yearsley was fought.

Hannah More to Elizabeth Montagu, 16 September 1785

Bristol 16 Sep 1785

My dear madam

It is grievous to me to disturb your elegant and happy retirement with the turbulent wickedness of the wretched object of your bounty. The Peace of my life is absolutely broken by her revenge; as I refuse to see her I had a letter from her lately of which I must torment you with an extract - le voici - - "Had your protection arisen from humanity my gratitude would have not have been erased, or had you been actuated by a disinterested desire to serve me; but your late treatment has set a narrow bounds to my gratitude; which cannot be avowed for favours which circumstances convince me arose more from your vanity than generosity. You tax me with ingratitude, for why? You found me poor yet proud, if it can be called pride to feel too much humbled by certain obligations, and above submitting to servility. You helped to place me in the public Eye; my success you think beyond my abilities, and purely arising from your protection; but granting this to your vanity, surely mine does not soar, in thinking the singularity of my situation wou'd have secured me some success: this will soon be tried. - but let me ask you what I have gain'd by your professed friendship? I find myself deprived of the money which my Poems, and the torturing tale of my distress have raised. My feelings and gratitude is traduced; but the public may yet discover my depressed situation. - I cannot think it ingratitude to disown as obligation a proceeding which must render me and my children your poor dependants for ever. I have trusted more to your probity than the event justifies. You have led me to sign a Settlement which defrauds me of my right, and makes it ever received your peculiar gift. Your bankruptcy or death may lose it for ever, and let me ask you Miss More what security you have ever given my children whereby they may prove their claim? I am sorry remonstrance is needful, or your motives left bare to doubt and suspicion. My mind is too haughty not to glory in being grateful for obligations it cou'd stoop to receive. If you are judged wrong confute my opinions on this depends my raising a Monument in my second Publication either to your just or unjust proceeding. The choice be Yours. - as its necessary for my character to be wrecked to do justice to Yours, I submit to it; in this it is your turn to be grateful

Ann Yearsley

Methinks my dear Madam, I see your noble indignation at reading this curious Epistle. To give up the Trust of the Funded Money just now, wou'd be sacrificing a duty to a fear, and appear, to her, at least, as if I were afraid to stand the scrutiny. Do not think, dear Madam that she will ever venture to abuse you, she has more sense. I shall be 
infinitely obliged to you to write me a few lines which may be reposted to her, to stay that you condescend to retain the Trust, till we can both rid ourselves of it by placing it in the hands of some responsible Person feel for your, dear Madam too exalted a veneration and love to let you be brought into my Scrape; grieved enough I am that I have been the means of your wasting your patronage and money on such a Wretch. You see she affects to name me only in the trust, and indeed I very imprudently told her that you wou'd have nothing to do with her, which she affected to take very noble and to be persuaded that you wou'd give it up to her. I laid out for her $£ 318$ to buy 350 in the $5 \mathrm{Pr}^{\mathrm{r}}$. Cents it is bought, as you were pleased to permit in your name and mine, I will send you the Bank Receipt for it \& the state of my $\mathrm{acc}^{\text {ts }}$ for this woman, if you will allow me; but I dread to give you trouble. I fear they have put me in the Papers: I take not the least notice of any of their Sensibilities (for she has a low fellow, one Shiells a Gardiner in London, who assists her) Nor shall I answer any of their letters. I take care of her affairs in the mean time and am bringing out a 2. ${ }^{d}$ Edit. in the advertise ${ }^{t}$. to which I have made this alteration that "The Editor has raised a very handsome Sum of Money which is placed in the Public Funds, vested in Trustees hands for the benefit of the author's Family". This is all the answer I think it necessary to make. - my dear Madam have the goodness to assure me that you will Strengthen my hands by letting your name $<$ stay $>$ for the present and I shall rejoyce to [unclear] it as soon as it can be done with dignity. $Y^{r}$. ever obliged \& faithful

Hannah More ${ }^{17}$

More's discussion about the funds suggests that she is anxious for her actions to have the appearance of transparency, offering as she does to send 'you the Bank Receipt for it \& the state of my acc ${ }^{\text {ts }}$ for this woman, if you will allow me,' which is rather more than is offered to Yearsley. However, this apparent desire for transparency extends only as far as financial matters. What Elizabeth Montagu could not know was the extent to which Hannah More had edited Yearsley's letter. Nor could she have seen that there are strong discrepancies between the two versions: More has removed some sections, and fabricated others, fundamentally altering the letter. I would like to argue here that these alterations were strategic and that through these alterations More was attempting to use her powers as a patron to undermine the authority Yearsley has attempted to claim as a mother.

More's first target is the excision of all of the original's courtesy. Yearsley's version opens with Yearsley writing 'I shall begin by avowing what my feelings will never allow me to be insensible of; your goodness in protecting my publication.' This is a clear and unambiguous acknowledgement of gratitude for More's patronage. Nor will this gratitude be forgotten - Yearsley's feelings will 'never allow' her to forget. Yearsley also closes with a formal courtesy, 'I am yr humble servant'. It might be argued that there is a hint of irony in the 'humble' close, given what has gone before in the letter, but Yearsley nevertheless affords More the expected courtesy. However, when the letter is transcribed for Elizabeth Montagu, there is no sign of the polite opening phrase. Nor has the close survived. Instead, Yearsley is represented as surly, rude, and bellicose-a description of her which might still be used by critics. This representation is entirely unjust, as the entire final section is different, as we can now see: all that follows 'The choice be yours' is absent from the original. Standing in sharp contrast with the bellicosity of 'I submit to it; in this it is your turn to be grateful' is More's own humble close, signing herself as ' $\mathrm{Y}$ r . ever obliged \& faithful Hannah More'. More ensures that she is seen to be following correct 
letter-writing protocol, whereas her 'savage' and uncivilised protégée is demonstrably ignorant of all such forms. More may have been 'faithful' to her friendship to Montagu, but she has been treacherous towards Yearsley.

This treachery has a distinct purpose. A comparison of the two letters reveals that More has extracted from specific sections of Yearsley's letter, from sections which do not feature references to Yearsley's children. It is this, I would like to argue, that is key to understanding why More edits Yearsley's letter. As we have seen, Yearsley is able to claim a great deal of power through her role as mother, and this power is seemingly discomfiting for More. It may also be that Yearsley's accusation that More has attempted to 'usurp' her protégée's place in her own family was not without merit; something which More would rather not have known to Montagu. Although this is supposition, the deliberateness with which More removes Yearsley's children from the letter is striking. Yearsley makes direct mention of her children seven times, and makes indirect references to them (as 'dependants', 'them', 'my family') a further three times. After More has edited the letter, only two direct references remain. By excising the children from the letter, More also removes Yearsley's language of maternity. More's version features no reference to 'rights' or the 'naturalness' of a mother's feelings. Yearsley's letter accused More of fraud, and of attempting to bypass, or neutralise Yearsley's authority as a mother in her letter's penultimate paragraph. If we look again at the same section, we can see how More's careful editing ensures that maternal authority is bypassed, and neutered:

you are too sensible there is no fund specified where it is placed nor do $1 \mathrm{know}$ how it is disposed of, there is no time assign'd when my Children shall call it out:) your bankruptcy or Death may lose it forever, and let me ask you Miss More what security you have ever Given my Children whereby they may prove their future Claim: ${ }^{18}$

Instead of Yearsley's children being central to this section, it is her own petulant-sounding 'let me ask you Miss More' that dominates. Yearsley appears belligerent, instead of the image of rational motherhood that her own letter attempted to convey. Her reasonable questions about the disposal of the fund are removed, and her remarks about More's 'bankruptcy' and the need for some 'security' are taken from their context. Hannah More has laid out for her $£ 318$ to buy 350 in the $5 \mathrm{Pr}^{\mathrm{r}}$. Cents', and has offered Montagu the receipts. Textual manipulation and clever framing means that Yearsley's concerns appear petty, even ridiculous.

More completes her counterattack on Yearsley's maternal authority with the removal of the word 'future' from this section. In her version, Yearsley makes it plain that her objections are to the way in which the fund had been established and managed. Yearsley's letter is also concerned with the apparent lack of thought that has been put into the long-term plans for the fund and its dispersal, but More's editing creates the impression that Yearsley wants the fund itself, and wants it now; Yearsley's statements that she 'wish'd not for money' and 'I wish not to squander the money' have been removed. Once again, More cleverly frames her editing, telling Montagu that 'To give up the Trust of the Funded Money just now, wou'd be sacrificing a duty to a fear, and appear, to her, at least, as if I were afraid to stand the scrutiny.' Just as Yearsley did in her letter, More is constructing roles for herself and her former protégée. Instead of wronged mother and unfeeling, inhuman woman, More has managed to cast Yearsley as the 'savage' of her own poetry, ignorant and aggressive, forward and rude. More herself is nobly doing what is right, characterised by her proposed 
advert that 'The Editor has raised a very handsome Sum of Money which is placed in the Public Funds, vested in Trustees hands for the benefit of the author's Family.'

In effect, this is a contest between two major social institutions: motherhood and patronage. Although motherhood clearly has an important public position, it is in a general sense. An individual who lays claim to the public power available to maternity risks the accusation of trading upon her private virtue for public and financial self-advancement, and perhaps of being a bad mother. Though Ann Yearsley is able to make compelling use of her status as a mother in the private domain of the letter, there is no way for the same arguments to be made in a more public arena. In contrast, the role of patron is both individual and public. Hannah More has an established right to make public declarations about her patronage of Ann Yearsley, meaning that Yearsley, as a protégée and a mother, is doubly silenced in the public realm. Even in the private world of letters, Yearsley's status as More's protégée means that she does not have the right to communicate with her illustrious supporters directly; the only legitimate channel is through Hannah More. This is an inequality that More exploits ruthlessly in her letter to Elizabeth Montagu. Using the conventions of patronage, More has been able to determine exactly how she represents herself and Yearsley to Montagu, and to the world at large. Yearsley had no socially acceptable way to respond in order to correct this deliberate misrepresentation of her character and conduct. Instead, Yearsley chose a socially unacceptable way, the publication in 1786 of 'Mrs. Yearsley's Narrative'. A double breach of social convention, Yearsley rejected with its publication the rules of public communication supposedly governing her both as a mother and as a protégée. The public condemnation which followed was immense, and was based on the charges of gross ingratitude made by More's friends. Since then, this dispute has been viewed in terms of Yearsley's failure to show gratitude towards her patron. Yet as we have seen, Yearsley's full acknowledgement of her sense of More's 'goodness' was remorselessly edited out, an abuse of More's patronal powers.

The new evidence within the letters between Yearsley and More indicates the scope of the power at a patron's disposal but, as we can see from the examples of other contemporary patronage relationships, the conflict that arose between Yearsley and More around that power was not unique. Rather, the parallels between Yearsley and Bloomfield, More and Lofft, as well as Clare and Taylor, Wordsworth and Lonsdale, Montagu and Woodhouse, and even perhaps Leapor and Freemantle, suggest that Yearsley should no longer be treated as a special case, singled out for being particularly belligerent or ungracious. Instead, she might usefully now be seen as the most public face of the tensions and disagreements which ran widely through many patronage relationships towards the end of the eighteenth century. Nottingham Trent University

Notes

1. See Mary Waldron, Lactilla, Milkwoman of Clifton: the Life and Writings of Ann Yearsley, 1753-1806 (Athens and London, 1996), 14-26.

2. The librarians at Tutt Library have been able to shed little light on the life of Alice Bemis Taylor, but what information they possess is available at the following site: http://www.coloradocollege. edu/Publications/Access/March-April1999/ Bemis.html

3. The underline is in a different, much darker, pen than the majority of the letter. The ink may be the same as the ink used to write the date.

4. The question mark is also an annotation.

5. Ann Yearsley to Hannah More, 13 September 1785 [Alice Bemis Taylor Autograph Collection, MS 0145, Colorado College Special Collections].

6. Ann Yearsley, 'Mrs Yearsley's Narrative', Poems on Various Subjects (London, 1787), xvi.

7. John Wolcot (Peter Pindar), Nil Admirari; or, A Smile at a Bishop (London, 1799), 17. 
8. Noah Heringman, "'Manlius to Peter Pindar": Satire, Patriotism, and Masculinity in the 1790s' in Romantic Circles Praxis Series, ed. by Orrin N. C. Wang, par. 16. http://www.rc.umd.edu/ praxis/patriotism/heringman/heringman_essay. html. Accessed 8.4.09.

9. Ann Yearsley to Hannah More, 13 September 1785.

10. Hannah More, 'Prefatory Letter' in Poems on Several Occasions by Ann Yearsley (London, 1785), iv-v.

11. Robert Bloomfield to Capel Lofft, 22 October 1801 [BL Add. MS 28268, f. 58].

12. Capel Lofft to Robert Bloomfield, 24 October 1801 [BL Add. MS 28268, ff. 60-61].
13. Samuel Johnson to Lord Chesterfield, February 1755, in The Life of Samuel Johnson, LL. D by James Boswell (2 vols., London, 1791), i. 142.

14. Robert Bloomfield to Capel Lofft, 26 October 1801 [BL Add. MS 28268, ff. 62-63].

15. 'To the Reader', in Poems upon Several Occasions by Mary Leapor (London, 1748).

16. Dustin Griffin, Literary Patronage in England 1650-1800 (Cambridge, 1996), 19.

17. Hannah More to Elizabeth Montagu, 16 September 1785, Huntington Library MO3992.

18. Ann Yearsley to Hannah More, 13 September 1785. I have struck out the sections that More removed from the original to indicate the extent of More's changes. These are not manuscript marks. 